\title{
The Impact of Total Quality Management on E-Government Implementation in Jordanian Governmental Institutions
}

\author{
Ali Abdallah Alatoum (Corresponding author) \\ Jerash University, Jordan \\ E-mail: ali.jo111@yahoo.com
}

Sohail Mohammad Bani Mustafa

Jerash University, Jordan

Received: July 30, 2021

Accepted: August 30, 2021

Published: December 23, 2021

doi: 10.5296/ijafr.v11i4.19370

URL: https://doi.org/10.5296/ijafr.v11i4.19370

\begin{abstract}
The primary goal of this research is to examine the impact of TQM and e-government on service quality within Jordanian public sector entities. To achieve the study's goal, a self-administered form was designed to elicit the opinions of seventy middle and senior managers from five government agencies.

The study's significance stems from its arrangement to clarify the impact of Total Quality Management and data technology collaboration on public-sector reform programs. Specifically, to assess the impact of the integrated relationship between the use of e-government and TQM on the quality of service provided by Jordan's public sector.

The study's findings revealed that the establishments studied used completely different dimensions of total quality management throughout the implementation of some stages of e-government. The findings also revealed a direct relationship between the development of Total Quality Management and e-government and service quality. Lastly, the study established the relationship and impact of the interaction between the application of TQM and e-government on public and service sector in Jordan.
\end{abstract}

Keywords: Total quality management, E-government, Service quality, Jordanian e-government 


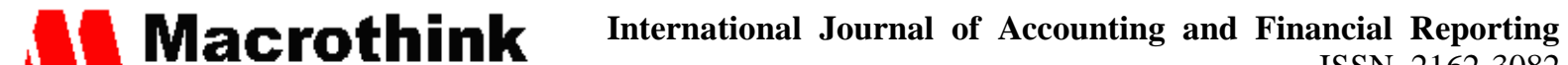 ISSN 2162-3082 2021, Vol. 11, No. 4}

\section{Introduction}

According to Campisi et al. (2013) information and communication technology (ICT) has been identified as a critical factor in the economic development and growth of nations, particularly in recent decades. ICT is also expected to change the way government agencies operate (Randma-liiv \& Kickert, 2017). The rapid development of ICT has a variety of effects on general aggressiveness. A positive outcome of ICT application can be found in a variety of areas, including the financial sector, health organizations, education and science, and government organizations (Khalil, 2011). The outcomes of ICT leverage have corrected its current use in public and private sectors. ICT has a reputation for improving public-sector outcomes, providing better services, and improving interactions with stakeholders and beneficiaries (Gronlund \& Horan, 2004).

E-government is also known as net governance, digital governance, and connected government. As of 2014, the Organization for Economic Cooperation and Development (OECD) continues to use the term digital government and differentiates it from e-government in its recommendation for the Public Governance Committee's e-government network (OECD, 2016). Many different definitions of e-government have emerged over time and with the advent of e-government (Gronlund, 2010). E-government is defined by the United Nations as "the use and application of data technologies for public administration to change and integrate workflows and processes, to effectively manage information and data, to improve public service delivery, and to broaden communication channels for participation and empowerment." (United Nations, 2014, p. 2).

What's meant by e-government implementation? The idea of "implementation" may be understood in numerous ways, for example, Fixsen et al. (2005) outline it as a swing into following associate activity or a program consisting of a nominal set of activities. E-government implementation refers to desegregation, at intervals government organizations, practices, or programs involving the employment of ICT to realize real goals.

After we name quality, it denotes that the service product, that we tend to manufacture or offer to customers or users, should be directed to appropriate purpose, free from errors and inaccuracies, convenient to use, and meet client demand. Additionally, quality in e-business is important because it encompasses the three basic metrics, which square measure quality management, internal control, and quality assurance. Manage, control and ensure quality in an e-services environment, evasion costs of conformity, that is, costs of detection and prevention, costs of nonconformity, which is, costs of internal failure and external failure, are necessary.

Nowadays, each public and private sides have placed high attentiveness upon total quality management, it's been used additionally in e-services, TQM may be a management system that's supported each one that is functioning within the organization ought to be committed to realize company's structural goals and meet the its high standards. The most target of a company is client gratification. TQM is an essential component of modern business. Everyone uses it, and it is especially important in e-services because most services are virtualized using information technology tools. 


\section{$\Lambda$ Macrothink}

International Journal of Accounting and Financial Reporting

ISSN 2162-3082

2021, Vol. 11, No. 4

The fulfillment of TQM within the e-services territory involves the direction of the team, systematic drawback finding, information derivers' call, applied math method and choice, and use of applicable problem-solving tools and techniques. The organizations with such skills in e-services do things higher as a result of their quick in communication, implementation, and decision-making, as well as achieving greater simplicity and adaptability in their processes. Using this approach, they will receive a faster response from their clients and may provide higher customer satisfaction. Using this approach, they will improve, grow, and develop the organization as well as their monetary and non-financial objectives. Square measurement is accomplished quickly and effectively.

Many studies have been conducted on the problem of TQM. In addition, public establishments that cared-for use the concept of e-government to market the affiliation between government establishments on the one hand, and voters and also the non-public sector on the other, in an attempt to provide effective and economical services and knowledge. Information-technology applications play an important role in improving TQM by establishing connections between customers and suppliers, team building, managing operations, and transmitting data between departments. Furthermore, the use of data technology applications advanced business methods, as did the use of preventative management and observation (Asia Oceanica Electronic Marketplace Association, 2004).

However, the character of e-government applications for real advantages continues to be troublesome to operate in developing countries (Joshi \& Islam, 2018). It's a tougher issue within the least developed countries (LDCs) that area unit classified by lower-income, weak human assets, and high economic vulnerability (United Nations, n. d). In such developing circumstances, e-government implementations are characterized by few advantages and even additional defeats (Gunawong and federal agency, 2017). As an example, gazing at the current standing of online services, the standard of transactional services within the LDCs lags so much behind in general. Such inferior conduct in this space cannot only be attributed to the retrograding socio-economic conditions prevailing there. Factors together with structure implementation problems and restricted context-tailored tools to be utilized in the application also can play necessary roles.

The up-to-date literature paints an image of restricted analysis on those problems within the least developed countries. This analysis investigates and contributes to the resolution of issues related to the implementation of e-government services in Jordan.

\section{Importance of the Study}

This paper is important as it contributes to explaining the importance of reform programs within public sector institutions, which would achieve administrative effectiveness as well as improve the quality of the final service provided to the public. As the work of the Jordanian public sector includes the implementation of a variety of measures in order to improve the quality of service provided to individuals and companies. These measures included process re-engineering, total quality management and e-government implementation. As these initiatives mainly aim to improve the level of service in the public sector, this is done by focusing more on customer satisfaction and raising the level of employee management. The 


\section{Ml Macrothink}

International Journal of Accounting and Financial Reporting

ISSN 2162-3082

importance of this study lies in its commitment to determine the impact of the integrative relationship between the application of e-government and total quality management on raising the level of service provided by the Jordanian public sector.

\section{Research Scope}

During this analysis, the e-government services unit is considered as public services delivered by the govt., or in partnership with the govt. "using data technologies to boost government data delivery and to enable citizens and businesses to create online transactions. (E-government services will embrace the availability of online certificates (e.g. birth, legal status...), land services, application for ID cards, driving licenses, etc. Implementation of these services in government organizations and on portals will come back the simple means. It needs complicated efforts associated with aspects of organization processes, people, technology, structure, and ensuing interaction of those aspects towards higher services. It's against that scenery, the main target of this paper is concerning impacts coupled with quality management processes within the implementation of e-government services.

\section{Objectives of the Study}

It's predictable that higher implementation of TQM can build an amendment within the market and organizations in the future. It'll facilitate with the management committee of all staff among the organization. Motivating all concerned in organization system add quality management and in an exceedingly systematic means can ultimately end in a more robust client and provider network. There's a break that it'll facilitate in achieving the structured goals and to assist \{the clients the purchasers, and the shoppers\} to attain customer satisfaction and understanding. The purpose of this study was to recognize the consequences of the application-level of e-government and TQM at the surveyed government establishments in Jordan. It also serves to assess the effects of implementing e-government techniques in the promotion of TQM in the long run. However, these two hampered service quality managements.

\section{Research Hypotheses}

The study included three variables: one independent variable representing the use of e-government, an intermediate variable representing the dimensions of TQM, and a dependent variable representing service quality. 


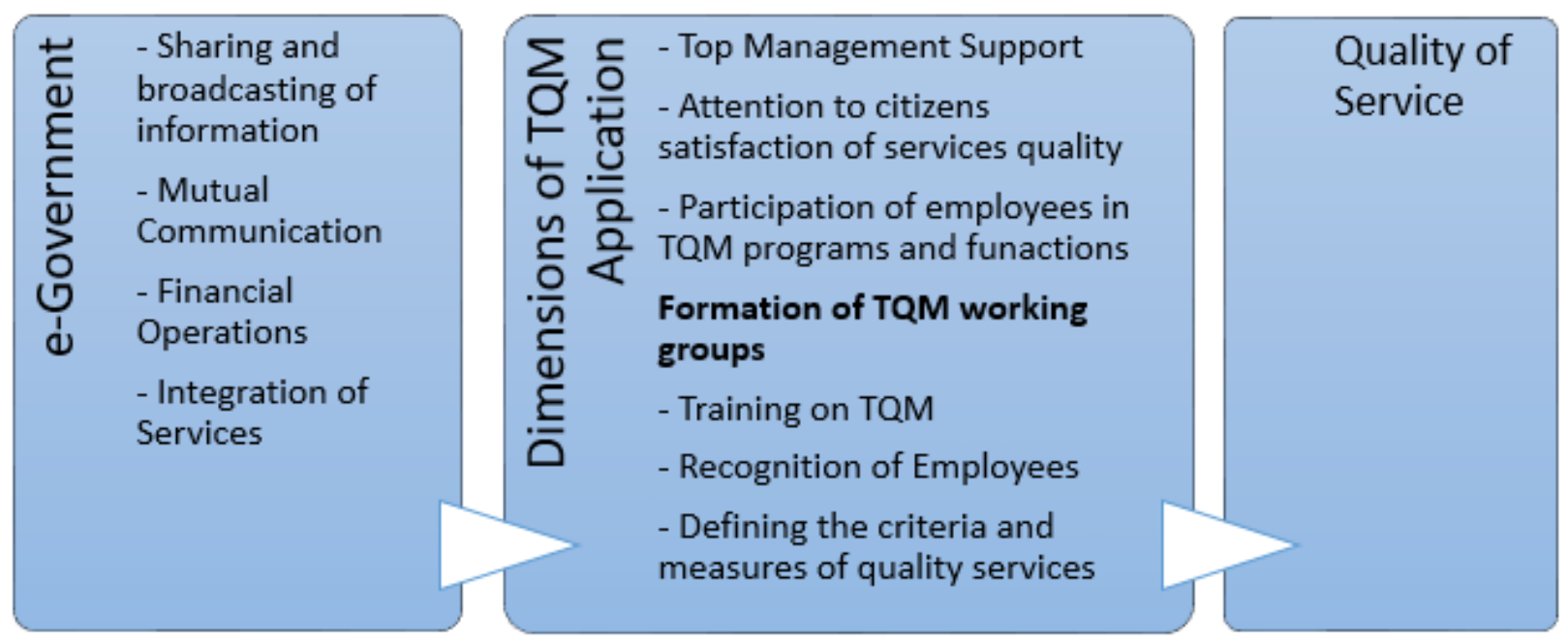

Figure 1. Model of the study

Based on the above model, the study consists of four hypotheses:

\section{The first hypothesis}

- There is a statistically significant impact of e-government implementation on service quality.

\section{The second hypothesis}

- There is a statistically significant effect of applying TQM on service quality.

\section{The third hypothesis}

- There is no statistically significant impact on the application of e-government on the application of total quality management.

\section{The Fourth hypothesis}

- There is a statistically significant impact of the application of total quality management and the application of e-government on improving service quality.

\section{Research Limitations}

Some of the constraints identified during the course of the study will be taken into account in order to put the leads into context. The study's limitations were a lack of time and a problem with generating adequate survey participation. As a result, I/we conducted a quantitative survey, but I/we only represent a few high-level executives. Second, the study is limited due to a lack of participation from respondents from various sectors such as citizens, university students, academia, banks, businesses, and non-governmental organizations (NGOs). The lack of analytical material for this study is the third limitation. I /we faced several difficulties to find materials from previous studies, particularly within Jordan experience. 


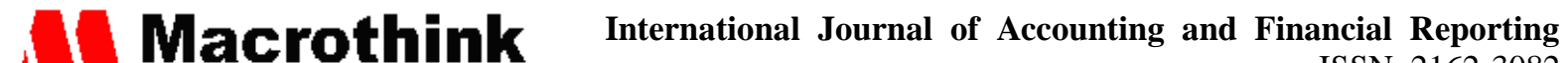 ISSN 2162-3082 2021, Vol. 11, No. 4}

\section{The Structure of the Paper}

\subsection{E-government}

Historically, prior to the establishment of an e-government system, government services relied primarily on traditional offline services in which government employees and citizens communicated in person. E-government may be a completely online service, with no face-to-face interaction between government employees and citizens, relying solely on web technology. This has ultimately resulted in lower management costs, increased management capability, and a promotion of action between totally different departments, as well as increased service capability (Baum, C. H., \& Di Maio, A, 2000).

E-government is a catch-all term for internet-based services provided by native, state, and federal governments. In e-governance, the government uses information technology, particularly the internet, to improve internal operations. E-government can be defined as a mechanism for delivering government services to the public via the internet or web applications developed on the market at a specific affiliation network. Interaction can also take the form of acquiring information, downloading forms, submitting e-filings or making online payments, participating in selections and votes, and a slew of other internet-based activities. Many authors and organizations have their own definitions and applications of e-government.

The following are some commonly used definitions: According to the World Bank (2011): "E-government" refers to the work of government agencies with information technologies (such as wide area networks, the internet, and mobile computing) that have the potential to transform relationships with citizens, businesses, and other government departments. These technologies will achieve a variety of objectives, including improved government services for voters, increased interactions with businesses, and voter empowerment through information access, as well as more efficient government administration. The ensuing edges may be reduced corruption, redoubled transparency, redoubled convenience, redoubled revenue, and/or reduced value.

The Organization for Economic Cooperation and Development (OECD) defines e-government as "the use of knowledge and communication technologies, primarily the internet, as an instrument to achieve higher government." Furthermore, (OECD, 2003:17) refines the definition as follows: "The term "e-government," as used by the OECD E-government Project, refers to the use of ICT as a tool to achieve higher government efficiency."

"E-government" is defined by Palvia and Sharma (2007: 1) as "the use of information technology, particularly the internet, to improve the delivery of state services to citizens, businesses, and alternative government agencies." E-government allows voters to move around and receive services from federal, state, and local governments 24 hours a day, seven days a week. A day, seven days a week, public administration to provide better services to citizens and to improve the internal structure and operation. For example, the Gov.Tax/Customs Duties workplace makes use of servers, computers, and internal networks to facilitate interactions between departments (this is taken into account as e-governance). Meanwhile, the tax/Customs Duties office may notify a tax-paying individual or company of 
the duties that must be paid, then collect the payments through online payment systems and send a payment confirmation to the payer (such activity is an example of a typical e-government service).

There is also an imbalance in the distribution of knowledge technology resources as well as citizens' ability to use them. In the e-government process at work, there are frequently instances where online and offline services are asynchronous. In the case of coexistence, several firms are selected online and offline in one of two ways, such as submitting residents for exit permits. Some aspects of the business should be completed online, while others should be submitted personally, even if there is no web affiliation, for example, income tax papers. As a result, these two processes of public business produce an experiment for citizens' perception of the standard of services (Lee et al., 2011).

There are two types of e-government users: citizens and businesses. There is a life cycle theory for government services, and for citizens, it is e-government services such as birth registration, education registration, social welfare, tax returns, and alternative business. E-government services for businesses primarily include establishment registration, tax declaration, customs, interstate advertising, and other business services. (Larsen, E., and L. Rainie, 2002) that e-government services should have access to government information, government forms and services, policy information, employment and business opportunities, and electoral information. tax archive files, registration and signature of the contract, pay the fine, and file all types of recommendation to the govt. up e-government services make these processes quicker, additional convenient, and additional economical, and will increase government transparency and answerability.

\subsection{Quality of Service}

In today's extremely competitive community, the necessity for quality is one every of the foremost vital factors to ensure the survival of state establishments in the international context TQM was introduced by government establishments as a useful tool for improving quality performance in the non-public sector, and it has been explored and implemented with reasonable success.

Improving service quality necessitates activity service quality, identifying characteristic gaps, and putting measures in place to close those gaps. RATER (responsiveness, assurance, tangibles, empathy, and reliability) is a useful model for assessing the quality of activity services. In addition, service quality improvements are frequently divided into three groups: comprehension, performance, and communication. As long as the organization is capable of correctly perceive the wants of the client, perform in accordance with those expectations, and communicate effectively throughout the method, it is possible to discover that the customers' perception of the service performance is aligned with the customer's expectations, which customers square measure thus pleased with the service quality of the organization. (Cosmin $\&$ tejerean, 2016).

E-government has structure and strategic dimensions. The structure factors might embody increased use of resources, ease info flow, and productivity enhancements. The strategy in using websites to succeed in wider users, or to boost government policy, together with the employment of technology. To stay these ambitions, the public services provided by the Gov. 
Websites ought to urge users' interactivity on multiple neutral platforms: citizens, organizations, and external interest or inquiry. Thus, a possible outcome of e-government is to boost the standard of services offered to citizens, one in every of that is comfy access to government info and services (Turban et al. 2008).

\subsection{Application of E-government}

The necessity of E-governance has been recognized in most of the nations of the globe and most of the countries square measure within the procedures of implementation of E-governance. The utilization of e-Government programs is currently within the public sector to extend potency and effectiveness of state operations; increase transparency and responsibility at government intervals, and supply public services in an additional appropriate and cost-efficient manner.

The following sub-variables were used to assess Jordan's level of e-government implementation:

1. Display of Information: This stage was discovered due to a lack of knowledge, and it is both basic and extreme. (United Nations, 2003). This side was measured by the website's ability to supply general info.

2. Joint Communication: This variant is characterized by sanction ativebiface communication via e-mail (Infodev, 2002). This variable was evaluated through the employment of a rating scale that assessed the user's ability to speak by e-mail, access info through databases, transfer forms, and link the positioning to alternative relevant locations of the establishment.

3. Financial Transactions: This stage assesses the flexibility to conduct monetary transactions to settle dues between the national and therefore the government. This variant claims to make strong infrastructure, info confidentiality, and security, and alter electronic payment (Baum \& DiMaio, 2000).

4. Service Integration: Upon reaching this stage of e-government action, Residents do not need to visit multiple government websites to obtain services because all government services are available on a single e-government website (Teicher, Hughes, Dow, 2002). Meet the social integration desires associated with ministry databases. Departments that have a computer network can then use an external network to achieve integration between government departments and partners from NGO establishments and alternative organizations. (Baum \& DiMaio, 2000; Benjamin Franklin Norris Jr. \& Moon, 2002).

\subsection{Dimensions of Quality Management}

Total Quality Management (TQM) could be a management track; it provides, in general, the continuous improvement in quality of products and services. It's a philosophy that emphasizes a scientific, integral, and coherent perspective that encompasses everybody and everything. TQM is often thought of a business philosophy with seven principles: client focus, leadership participation, quality assurance, continuous improvement, worker direction, provider partnerships, and strategic quality setup (Lai, KH, Weerakoon, TS, \& Cheng 


\section{Mll Macrothink}

International Journal of Accounting and Financial Reporting

ISSN 2162-3082

2021, Vol. 11, No. 4

ethylene, 2002). TQM begins with the expectation of the client and anyone within the organization can place himself within the place of the client. Even though the worker doesn't have direct contact with an of doors client, he should conjointly perceive however prepared the shopper's square measure for a product or service.

TQM was measured across seven dimensions: prime management direction for total quality performance, concern for citizens' satisfaction with service quality, worker involvement in QM programs and functions, formation of TQM operating teams, TQM coaching, worker recognition, and decisive factors for activity service. These variables are assessed using a five-point Likert-type scale. The size was provided. the solution choices of powerfully pain the relative weight of 1 degree, the solution does not trust the relative weight of 2 degrees, the solution neutral with the relative weight of 3 degrees, the solution trusts the relative weight of 4 degrees, and thus the answer powerfully agrees with the relative weight of 5 degrees.

\section{Literature Review}

\subsection{Total Quality Management}

In recent years, increasing pressure has pushed government establishments in Jordan to implement TQM. Among the foremost distinguished reasons square measure, the will to boost the standard of service provided to voters, increase productivity and scale back operational expenses. Thus, TQM could be a company culture dedicated to client satisfaction through continuous improvement, and this culture differs from country to country and from sector to sector, however, it's clear common values which will be applied to confirm full market share, increase profit and scale back prices (Ghaffarkadhim et al., 2019). TQM could be a philosophical conception supported by the appliance of a collection of principles and pointers to boost service and merchandise quality (Palo \& Padhi, 2003). To confirm long-run success and improve the potency of business processes, these principles should be applied absolutely and endlessly (Rosenhoover \& Richard Kuhn, 1996). TQM opinion is that the complete methodology for the continual development of merchandise, services, equipment, procedures, atmosphere, and personnel to satisfy shopper desires and reach the higher limit of profit (Zhengwei et al., 2019).

According to Besterfield et al. (2003), the QM implementation aims to achieve a number of goals:

1. Meet this and the future desires of shoppers.

2. Increase the fight of the organization.

3. Increasing the productivity of all components of the organization.

4. Increase the institution's ability to subsume completely different environmental variables and challenges.

5. Achieving continuous improvement all told aspects of the organization's functions.

6. Increasing the organization's power to drive continuous growth in order to achieve the most effective position among competitive organizations. 
7. Rising the profit of the organization.

According to Psychogios and Priporas (2007), Quality Management Concepts is divided into two parts: the first focuses on management ideas and principles (Soft), and the second focuses on techniques and tools (Hard), as summarized later:

Table 3. Quality management concepts and tools

\begin{tabular}{cl}
\hline TQM systems, tools and techniques (hard) & Concepts and principles related to TQM (soft) \\
\hline 1. Statistical process control & Participation of workers \\
2. ISO 9000 series & Continuous improvement \\
3. Pareto analysis & TQM training \\
4. Matrix analysis and diagram & Working teams \\
5. Recurring polygon & Top management support \\
6. Decision tree analysis & Democratic style of management \\
7. Critical path analysis & Consumer satisfaction \\
8. Fishbone analysis and model & Cultural change \\
9. & Empowerment \\
\hline
\end{tabular}

Muslim et al. (2020) known eleven total quality management activities, namely, management engagement, quality management, coaching and education, worker engagement, continuous improvement, provider collaboration, product/service style, quality knowledge and news policy, communication to reinforce quality and client satisfaction orientation.

\subsection{E-government}

Three primary features of e-government are addressed in the literature:

\subsubsection{E-Government Definition and Characteristics}

E-government can imply many different things to different people. Some observers define e-government in terms of specific behaviors, such as using a government stall to obtain employment information, creating common databases for numerous agencies. Various commentators define e-government as the automation of the delivery of presidential services. While there are many different perspectives on e-government, there are certain common aspects that highlight the organic nature of the process.

E-government is outlined because of the $24 / 7$ provision of permanent government data and services to voters (Norris and Moon, 2005). It's additionally outlined because of the use of technology-based websites to disseminate and provide government services, which is a global trend in the public sector (Wong \& Welch, 2004). Gil-Garcia and Pardo (2006) divide e-government into four dimensions: e-services, e-governance, e-commerce, and e-democracy. The website's e-government application is not limited to commercial firm electronic services, however additionally goes on the far side that.

"The use of web technologies and standards to rebuild agency effectiveness, efficiency, and repair quality," according to Mark Forman, Associate Director for Data Technology and E-Government at the Office of Management and Budget (OMB) (Stephen Barr, 2001). 


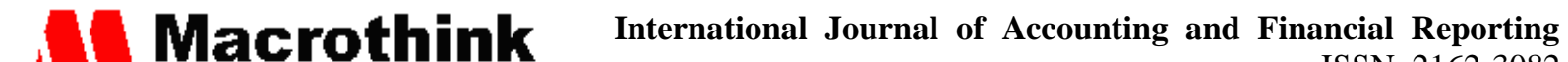 ISSN 2162-3082 2021, Vol. 11, No. 4}

\subsubsection{Stages of E-government Application}

Many studies conducted on the topic of e-government divided the stages of e-government implementation into three phases (InfoDiff, 2002), and different studies divided them into four phases (Baum and Dimayo, 2000), and a few into five phases. Meanwhile, the various phases raised, there square measure similarities between the parts of the appliance within the sense that two phases are combined in one phase (Asia archipelago Electronic Marketplace Association, 2004). Here square measures a number of the foremost well-liked studies during this space. Per a study conducted by the planet Bank (Infodev, 2002, pp. 3-5), the three stages: publication, interaction, and dealings for e-government implementation. Within the commercial enterprise stage, an amazing quantity of data like legislation, rules, and forms is disclosed on the e-government website. This knowledge is provided to voters and corporations. The second level, interaction, allows for mutual communication between the government and voters via e-mail. Individuals will interact with decision-makers as part of the governance system. The third stage, transactions, allows citizens and the government to conduct financial transactions in a way comparable to e-commerce in the private sector.

The use of e-government, according to writer and DiMaio (2000), passes through four levels: presence, interaction, transaction, and transformation.

\section{Phase 1: Presence}

Presence is that the 1st stage of development and is making a placeholder for presenting data within the future. It represents the best and least overpriced entry to e-government; however, it additionally provides the fewest choices for voters. A typical example could be a basic website that lists fast data concerning the workplace, like business hours, address, and/or phone numbers, however doesn't have interactive capabilities. It's a negative show of general data. Some observers consult with these styles of websites as "adware," indicating that they're the electronic equivalent of a paper folder.

\section{Phase 2: Interaction}

Interaction is the second stage. Despite the fact that interactive Web-based projects expand capabilities, activities in this cluster are still limited in their ability to shape and automate government functions. Interactions are usually straightforward and revolve around the provision of data. These sorts of initiatives are designed to assist the client to void a visit to an associate workplace or build telephony by creating ordinarily requested data and forms obtainable round the clock. These resources could embody directions for getting services, downloadable forms to be written and armored back to center, or maybe e-mail contact to retort to straightforward queries.

\section{Phase 3: Transaction}

The second stage is that the reaction. Though interactive web-based initiatives offer improved capabilities, efforts during this cluster stay restricted in their ability to modify and automatize government jobs. The interactions are comparatively straightforward and usually revolve around providing data. These sorts of initiatives are designed to assist a client to void a visit 
to the workplace or creating telephony by providing ordinarily requested data and forms round the clock. These resources would possibly embody directions for getting services, downloadable forms to print and mail to the center, or maybe associate email contact to answer straightforward queries.

\section{Phase 4: Transformation}

Transformation is the highest ranking of evaluation for e-government. Initiatives at this level use the total potential of technology to rework however government jobs are conceptualized, organized, and enforced. Initiatives like these can have robust client relationship management capabilities needed to take care of a full vary of queries, issues, and needs. At the instant, there are only a few samples of this kind of initiative, partially because of body, technical and monetary limitations. One difference between these projects is that they enable the smooth flow of data and collaborative decision-making among federal, state, municipal, public, and private partners. In other words, transformative e-government efforts frequently ask for the removal of restrictive hurdles that promote agency-centric solutions in favor of customer-centered ones. Some proponents argue that, at its most evolved level, e-government would reorganize, integrate, and/or eliminate current agencies in favor of virtual ones.

The four phases of e-government are emerging presence, enhanced presence, transactional presence, and networked presence, according to the United Nations (2003). Basic and restricted data are provided through the growing presence section. During the upgraded stage, the e-government website provides more current and archived public policy and governance information, such as policies, laws, and regulations, reports, newsletters, and downloadable databases. During the interactive-presence stage, voters will respond quickly to government officials. During this phase, voters will be able to use the internet to pay taxes and apply for identification cards, birth certificates, and passports at any time of day or week. Voters will interact in decision-making through tools such as online comment forms and new consultation methods in the networked-presence stage, which is regarded to be the most polished of all.

\subsubsection{E-Government and the Application of Total Quality Management}

Fuller, St. George, and Valatsich (2008) and Koh, Ryan, and Pribotok (2005) both state that using e-government to promote TQM implementation can be accomplished through team building and therefore the usage of a group call support strategy, and coaching employees on the ideas and principles of TQM by adding a coaching channel on-line. Moreover, the applying of e-government facilitates continuous improvement of quality by enhancing specialization in the user of services, achieving coordination and integration between government entities as well as effective and cost-effective interaction and interchange of monetary transactions with government agencies (Von Haldenwang, 2004).

The e-government formation promoted the continual adjustment by moving forward with the supply of electronic services. E-government services begin by business enterprise data on a website, then it facilitates mutual interaction between the govt. and repair recipients, so creates a unified platform web site through that a private will organize and manage a 
collection of desires and services. Since the e-government depends on electronic management, it participates in augmentating the capability of presidency establishments, developing strategies of communication between levels of administration and, scattering data among workers (Laudon \& Laudon, 2004). The variety of services available on the e-government portal is made possible by collaboration and integration across many government agencies (Breen, 2000). It's also been established that the e-government application aids senior managers in instilling quality values in employees, improving communication and engagement between senior managers and employees, enhancing senior managers' ability to observe operations, and facilitating communication between senior managers, consumers, and suppliers. (Nguyen, 2006).

\section{Methodology}

This study used the descriptive analytical approach at the side of the sphere study methodology. The results of the Cronbach alpha-test instrument incontestable a degree of stability within the participants' responses, as shown in Table 1:

Table 1. Cronbach's Alpha Results

Variables of the study

E-government

Quality of service

QM
Value of Cronbach's alpha

$94.99 \%$

$97.14 \%$

\section{The Sample of the Study}

The study population comprised establishments that have functioning on the appliance of e-government within the Hashemite Kingdom of Jordan. To understand the goals of this study, the researchers used a sample of 5 government institutions: The Senate, the Department of Land and House, the Protection Repository Center, the Jordan Establishment for Standards and Scientific Discipline, and therefore the Corporation's Management Department.

The researchers arbitrarily distributed seventy copies of the study survey and were ready to elicit responses from fifty-six participants. This equates to eightieth percent of all surveys. Table 2 shows the characteristics of the surveyed sample. 


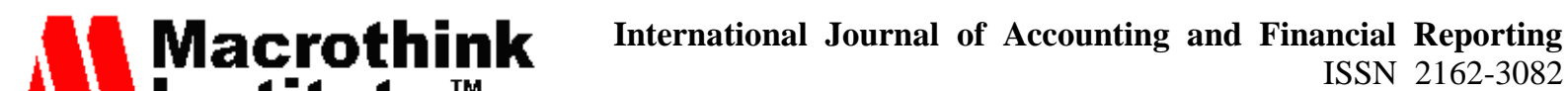 2021, Vol. 11, No. 4}

Table 2. Frequency Distribution of Respondents

\begin{tabular}{|c|c|c|}
\hline 1. Job position & Repetition & Percentage \\
\hline Senior management & 7 & 12.5 \\
\hline Middle management & 49 & 87.5 \\
\hline \multicolumn{3}{|c|}{ 2. Educational qualification } \\
\hline Graduate & 11 & 19.6 \\
\hline Higher diploma & 5 & 8.9 \\
\hline Bachelor & 32 & 57.1 \\
\hline Community college & 8 & 14.3 \\
\hline \multicolumn{3}{|c|}{ 3. Number of years of services in the organization } \\
\hline 5 years or less & 6 & 10.7 \\
\hline $6-10$ years & 24 & 42.9 \\
\hline $11-15$ years & 14 & 25.0 \\
\hline More than 15 years & 12 & 21.4 \\
\hline
\end{tabular}

\section{Statistical Methodology and Approach}

The researchers selected the subsequently applied math strategies to method the data:

- Frequencies, averages, and customary deviations were accustomed to describe the characteristics and variables of the study sample.

- Simple and multivariate analysis was accustomed check the hypotheses of the study.

- Serial regression was accustomed to check the interaction between the employment of e-government and therefore the application of quality management in raising service quality.

\section{Statistical Analysis and Hypothesis Testing}

\subsection{The Application of the Concept of E-government}

The outcomes regarding the implementation of the conception of e-government area unit conferred in Table four. The results explained that surveyed establishments apply the conception of e-government in information participation and allocation at a mean of four.15; in joint communication at a mean of three.76, and within the implementation of integrated services among numerous government sections at a mean of three.13. As for the mean of the electronic financial-transaction process, it had been lower at a pair of.40. Due to implementing this stage of e-government, there's a requirement to prevalence the culture of e-government between voters and condense on the protection of monetary transactions through the web. The quality deviation confirms contradiction among the responses of the study sample. 
Table 4. The mean and standard deviations for the application of e-government

\begin{tabular}{lll}
\hline \multicolumn{1}{c}{ Application of e-Government } & Mean & Standard Deviation \\
\hline Sharing and Broadcasting of Information & 4.15 & 1.030 \\
Mutual Communication & 3.76 & 1.040 \\
Financial Operations & 2.40 & 1.0870 \\
Integration Services & 3.13 & 0.948 \\
\hline
\end{tabular}

\subsection{The Application of TQM}

The results in Table 5 show that the establishments surveyed were committed to implementing TQM. When it came to the perimeters by which TQM was implemented, firms' senior-management support and employee involvement in TQM programs were all above average. The end result illustrates the fact that public sector organizations in Jordan are attempting to implement TQM principles.

Table 5. The Mean and Standard Deviations of TQM

\begin{tabular}{lll}
\hline \multicolumn{1}{c}{ Dimensions of Quality Management } & Mean & Standard Deviation \\
\hline Top-management support & 4.21 & 0.867 \\
Attention to citizens satisfaction of service quality & 4.15 & 0.809 \\
Participation of employees in TQM programs and functions & 4.00 & 0.965 \\
Formation of TQM working groups & 3.81 & 1.091 \\
Training on TQM & 3.78 & 0.989 \\
Employee's recognition & 3.71 & 1.178 \\
Defining the criteria and measures of quality service & 3.70 & 0.999 \\
\hline
\end{tabular}

\section{Testing the Hypotheses of the Study}

$\mathrm{H}_{0}$ 1: there's no statistically vital impact of the implementation of e-government on the standard of service. To check this hypothesis, a regression model was applied. As shown in Table 6, the outcomes dictate a positive relationship between the appliance of e-government and therefore the level of quality of service at 0.681 . Further, the worth of the Coefficient of Determination $\left(\mathrm{R}^{2}\right)$ demonstrates that the appliance of e-government accounted for $46.3 \%$ of the inconsistency within the variable of quality of service. as a result of the worth of $\mathrm{T}=6.828$ and therefore the significance level $=.00$, this null hypothesis was acceptable and therefore the substitution one was unaccepted. This denotes a statistically significant impact of the implementation of e-government on the quality of the public sector services; this impact of e-government expresses $46.3 \%$ of the quality of services. 


\section{Macrothink \\ International Journal of Accounting and Financial Reporting \\ ISSN 2162-3082 \\ 2021, Vol. 11, No. 4}

Table 6. Results of the Simple Regression Model for $\mathrm{H}_{0} 1$

\begin{tabular}{cccccc}
\hline Independent Variable & $\mathrm{R}$ & $\mathrm{R}^{2}$ & $T$ Value & $\begin{array}{c}\text { Significance } \\
\text { Value }\end{array}$ & F Value \\
\hline Application of e-Government & 0.681 & 0.463 & 6.828 & .000 & $? ? ?$ \\
\hline
\end{tabular}

$\mathrm{H}_{0}$ 2: there's a statistically vital impact of the implementation of TQM on the standard of service. To check this hypothesis, the applied math multiple-regression model was applied. As illustrated in Table 7, the results gift a positive relationship between the appliance of overall quality and therefore the quality of service at 0.606 . The worth of the Coefficient of Determination constant $\left(\mathrm{R}^{2}\right)$ exhibits that the appliance of overall quality demonstrates $36.7 \%$ of the variance within the variable of quality of service. Thus the worth of $\mathrm{T}=3.888$ and therefore the significance level $=.002$, the null hypothesis was accepted and therefore the different one was rejected. This recommends that there's a statistically vital impact of the appliance of the quality of services.

Table 7. Results of the Multiple Regression Model for $\mathrm{H} 02$

\begin{tabular}{cccccc}
\hline Mediator Variable & $\mathrm{R}$ & $\mathrm{R}^{2}$ & $T$ Value & $\begin{array}{c}\text { Significance } \\
\text { Value }\end{array}$ & $\mathrm{F}$ Value \\
\hline Application of TQM & 0.606 & 0.367 & 3.888 & .0002 & $? ? ?$ \\
\hline
\end{tabular}

$\mathrm{H}_{0}$ 3: there's no statistically vital influence of the appliance of e-government on the appliance of TQM. To check this hypothesis, the applied math simple-regression model was exercised. The results, shown in Table 8, signify a sway of applying e-government on the assorted dimensions of quality tested within the study. The implementation of e-government affected top-management improvement at a price of $\mathrm{t}=3.788$ and therefore the significance level $=.000$, attention to voters happiness of service quality at the price of $t=17.844$ and therefore the significance level $=.000$, participation of staff in TQM programs and functions at $\mathrm{t}=$ 5.695 and therefore the significance level $=.021$, figuration of TQM operating teams at a price of $t=6.165$ and therefore the significance level $=.016$, process the quality and measures of quality service at the price of $t=7.010$ and therefore the significance level $=.011$. What is more, the results of the study showed no impact of e-government application on TQM coaching $(\mathrm{t}=1.961$ and therefore the significance level $=.167)$ and recognition of staff $(\mathrm{t}=0.853$ and significance level $=.360)$. 
Table 8. Results of the Simple Regression Model for $\mathrm{H}_{0} 3$

\begin{tabular}{llll}
\hline \multicolumn{1}{c}{ Dimension of TQM Implementation } & \multicolumn{1}{c}{$\mathrm{R}^{2}$} & $\begin{array}{c}\text { Value } \\
\text { of } T\end{array}$ & $\begin{array}{c}\text { Significanc } \\
\text { e Value }\end{array}$ \\
\hline Top-management support & 0.210 & 3.788 & 0.000 \\
Attention to citizens satisfaction of service quality & 0.252 & 17.844 & 0.000 \\
Participation of employees in TQM programs and functions & 0.097 & 5.695 & 0.021 \\
Formation of TQM working groups & 0.104 & 6.165 & 0.016 \\
Training on TQM & 0.035 & 1.961 & 0.167 \\
Employee's recognition & 0.016 & 0.853 & 0.360 \\
Defining the criteria and measures of quality service & 0.115 & 7.010 & 0.011 \\
\hline
\end{tabular}

$\mathrm{H}_{0}$ 4: there's a statistically extensive impact of the implementation of TQM and therefore the application of e-government on evolving service quality to check the integrated relationship between the size of application of e-Government and implementation of TQM on the standard of service, the sequential-regression model was used. The end result is conferred in Table 9 and detailed below:

1- The researchers coated the results of applying TQM to service quality (F price $=3.888$ and significance level $=.002$ ).

2- After adding the e-government application variable to the model, the results showed that the extra variable raised the interpretation constant by 0.279 , whose price is of informative applied math significance $F=36.256$ and therefore the level of significance $=0.000$. This brings the whole informative price to $64.6 \%$.

3- After adding the interaction variable between the appliance of e-government and therefore the dimensions of total quality management to the study model. The results of the study showed that the else variable increased the informative issue with a price of 0.184 that could be a statistically vital level at $F=6.050$ price and a significance level $=0.000$. Therefore, the whole informative price was eighty-three percentages.

Table 9. Results of the Sequential Regression Model for $H_{0} 4$

\begin{tabular}{llllllll}
\hline Step & Independent Variable & $R^{2}$ & $F$ & $\begin{array}{l}\text { Significa } \\
\text { nce Level }\end{array}$ & $\begin{array}{l}\text { Rate of } \\
\text { Change } \\
R^{2}\end{array}$ & $F$ & $\begin{array}{l}\text { Signific } \\
\text { ance } \\
\text { Level }\end{array}$ \\
\hline $1 \quad$ & $\begin{array}{l}\text { The dimensions of } \\
\text { overall quality }\end{array}$ & 0.367 & 3.888 & 0.002 & 0.3888 & 3.871 & 0.002 \\
$2 \quad \begin{array}{l}\text { E-government } \\
\text { Application }\end{array}$ & 0.646 & 36.256 & .000 & 0.279 & 36.256 & .000 \\
\hline $\begin{array}{l}\text { Interaction between } \\
\text { e-Government and the } \\
\text { dimensions of TQM }\end{array}$ & 0.830 & 6.050 & .000 & 0.184 & 6.050 & .000 \\
\hline
\end{tabular}




\section{Macrothink \\ International Journal of Accounting and Financial Reporting \\ ISSN 2162-3082 \\ 2021, Vol. 11, No. 4}

\section{Discussion and Results}

The research study's findings are mentioned below:

1. At the most basic level of implementation, the institutions questioned advised using e-government for data sharing and distribution, mutual communication, service integration between multiple government agencies, and the processing of financial transactions over the Internet. The absence of minimal support for financial transactions over the Internet can be excused by the lack of a knowledge of the poor degree of security and confidentiality of data among service recipients, as well as the lack of well-defined regulations and legislation.

2. The introduction of e-government has a statistically significant impact on TQM employment.

3. The use of e-government has an impact on some aspects of TQM implementation, such as senior management support, citizen satisfaction with service quality, employee participation in TQM programs and functions, the formation of TQM work groups, and the establishment of service quality standards and measures. The study's findings, on the other hand, found no evidence of a major impact of e-government on TQM training and employee recognition. The lack of impact of e-government adoption on TQM training, according to the researchers, is due to a lack of knowledge and process integration amongst government agencies. As a result of this lack of integration, TQM knowledge and implementation are only widely disseminated. This restriction also adds to the frustration that Jordan's e-government adoption is still in its early phases and is not yet complete. According to researchers, employee recognition is heavily influenced by other elements like leadership systems, awards, and salaries, which are heavily influenced by other elements like salary. The connectivity of e-Government with TQM has a statistically significant impact on Jordan's public sector service quality. However, this paper recommended to encouraging more research on the problem, which should cover all Jordanian governmental organizations, as this study only looked at five.

\section{References}

Asia Oceania Electronic Marketplace Association. (2004). E Government from a user's perspective. Proceedings of the 29th meeting of the APEC Telecommunications and Information Working Group (pp. 1-218). Retrieved from http://www.old.gartner.com/public/static/hostc/00094235.html

Barr, S. (2001). President Searching for a Few Good E-Government Ideas. Washington Post, August 10, p. B2.

Baum, C. H., \& Di Maio, A. (2000). Gartner's four phases of e government model. Retrieved January 28, 2008, from http://www.gartner.com

Besterfield, D. H., Besterfield-Michna, C., Besterfield, G. H., \&Besterfield-Sacre, M. (2003). Total quality management (3rd ed.). Upper Saddle River, NJ: Pearson-Prentice Hall. 
Breen, J. (2000). At the dawn of e-government: The Citizen as Customer. Government Finance Review, 16(5), 15-20.

Campisi, D., de Nicola, A., Farhadi, M., \& Mancuso, P. (2013). Discovering the impact of ICT, FDI and human capital on GDP: A Cross-sectional analysis. International Journal of Engineering Business Management, 5, 110.

CosminStejerean. (2016). Medium, Measuring and Improving Service Quality. Retrieved from https://link.medium.com/Yfx7wbiycgb

Fixsen, D. L., Naoom, S. F., Blasé, K. A., Friedman, R. M., \& Wallace, F. (2005). Implementation Research: A Synthesis of the Literature. Tampa, FL: University of South Florida, Louis De la Parte Florida Mental Health Institute.

Fuller, M., George, J., \& Valacich, J. (2008). Information systems project management. Upper Saddle River, NJ: Prentice Hall.

Ghaffarkadhim, K., Harun, A., \& Othman, B. A. (2019). Hypermarkets in Malaysia: Issues of expansion, distribution and corporate social responsibility. International Journal of Psychosocial Rehabilitation, 23(2), 659-670.

Gil-Garcia, J. R., \& Pardo T. A. (2006). Multi-method approaches to understanding the complexity of e-government. International Journal of Computers, Systems and Signals, 7(2), 3-17.

Gronlund, A. (2010). Ten Years of E-Government: The "End of History". In IFIP International Federation for Information Processing 2010 (pp. 13-14).

Gronlund, A., \& Horan, T. A. (2004, June). Introducing e-GOV: History, Definitions, and Issues. Communications of the Association for Information Systems, 15, 713-729.

Gunawong, P., \& Gao, P. (2017). Understanding e-government failure in the developing country context: a process-oriented study. Information Technology for Development, 23(1), 153-178.

Huang, Z. W., Pei, X. Ke., Xi, J., Othman, B., \& Sher Ali, L. L. (2019). The Influence of Consumers' Perception on Perceived Value and Purchase Intention with respect to Regional Products Based on a C-A-B Model Vplivdojemanjapotrošnikanazaznanovrednost in na C-A-B. Tekstilec, 62(3), 219-228.

Infodev. (2002). The e-government handbook for developing countries (Working paper). Geneva, Switzerland: The World Bank Group.

Joshi, P., \& Islam, S. (2018). E-Government Maturity Model for Sustainable E-Government Services from the Perspective of Developing Countries. Sustainability, 10(6), 1-28.

Khalil, O. E. M. (2011). E-government readiness: Does national culture matter?. Government Information Quarterly, 28(3), 388-399. 


\section{Macrothink}

International Journal of Accounting and Financial Reporting ISSN 2162-3082

Koh, C. E., Ryan, S., \& Prybutok, V. R. (2005). Creating value through managing knowledge in an e-government to constituency (G2C) environment. The Journal of Computer Information Systems, 45(4), 32-41.

Lai, K. H., Weerakoon, T. S., \& Cheng T. C. E. (2002). The state of quality management implementation: A cross-sectional study of quality-oriented companies in Hong Kong. Total Quality Management, 13, 29-38. https://doi.org 10.1080/09544120120098546

Larsen, E., \& Rainie, L. (2002). The rise of the e-citizen; How people use government agencies' Web sites Washington D.C.: Pew Internet and American Life Project.

Laudon, K. C., \& Laudon, J. P. (2004). Management information system: Managing the digital firm. Upper Saddle River, NJ: Pearson.

Lee, J., Kim, H. J., \&Ahn, M. J. (2011). The willingness of e-Government service adoption by business users: The role of offline service quality and trust in technology. Government Information Quarterly, 28(2), 222-230. https://doi.org/10.1016/j.giq.2010.07.007

Muslim, A., Harun, A., Ismael, D., \& Othman, B. (2020). Social media experience, attitude, and behavioral intention towards umrah package among generation $\mathrm{X}$ and $\mathrm{Y}$. Management Science Letters, 10, 1-12.

Nguyen, T. Q. L. (2006). Improving performance through linking IT and TQM in Vietnamese organizations (Unpublished Thesis). University of Fribourg, Fribourg, Switzerland.

Norris, D. F., \& Moon, M. J. J. (2005). Advancing e-government at the grassroots: Tortoise or hare? Public Administration Review, 65, 64-75. https://doi.org/10.1111/j.1540-6210.2005.00431

Palo, S., \& Padhi, N. (2003). Measuring effectiveness of TQM training: An Indian study. International Journal of Training and Development, 7, 203-216. https://doi.org/10.1111/1468-2419.00181

Palvia, S. C., \& Sharma, S. S. (2007). E-Government and E-Governance: Definitions/Domain Framework and Status around the world. Retrieved July 10, 2011, from http://www.iceg.net/2007/books/1/1_369.pdf

Psychogios, A. G., \& Priporas, C.-V. (2007). Understanding total quality management in context: Qualitative research on managers' awareness of TQM aspects in the Greek service industry. The Qualitative Report, 12, 40-66.

Public Governance; Territorial Development Directorate. Recommendation of the Council on Digital Government Strategies 2014, page 6. OECD. Retrieved 10 April, 2016.

Randma-Liv, T., \& Kickert, W. (2017). The Impact of the Fiscal Crisis on Public Administration Reforms: Comparison of 14 European Countries. Journal of Comparative Policy Analysis: Research and Practice, 19(2), 155-172.

Rosenhoover, D. E., \& Kuhn, H. W. Jr. (1996). Total quality management and the public sector. Public Administration Quarterly, 19, 435-455. 


\section{MInstitute ${ }^{\text {Mink }}$}

International Journal of Accounting and Financial Reporting ISSN 2162-3082

Teicher, J., Hughes, O., \& Dow, N. (2002). E-government: A new route to public sector quality. Managing Service Quality, 12, 384-393. https://doi.org/10.1108/09604520210451867

Turban, E., Leidner, D., McLean, E., \& Wetherbe, J. (2008). Information Technology for Management: Transforming Organizations in the Digital Economy (6th ed.). New York: Wiley \& Sons.

United Nations (n. d.). LDC Identification Criteria \& Indicators. Retrieved from https://www.un.org/development/desa/dpad/least-developed-country-category/ldc-criteria.ht $\mathrm{ml}$

United Nations Public Administration Programme. (2003). World public sector report 2003: E-government at the crossroads. New York, NY: Author.

United Nations. (2014). United Nations E-government Survey 2014. Retrieved from https://publicadministration.un.org/egovkb/Portals/egovkb/Documents/un/2014-Survey/E-Go v_Complete_Survey-2014.pdf

Von Haldenwang, C. (2004). Electronic government (e-government) and development. European Journal of Development Research, 16, 417-432. https://doi.org/10.1080/0957881042000220886

Wong, W., \& Welch, E. (2004). Does e-government promote accountability? A comparative analysis of website openness and government accountability. Governance, 17, 275-297. https://doi.org/10.1111/j.1468-0491.2004.00246

\section{Copyright Disclaimer}

Copyright for this article is retained by the author(s), with first publication rights granted to the journal.

This is an open-access article distributed under the terms and conditions of the Creative Commons Attribution license (http://creativecommons.org/licenses/by/4.0/) 